\title{
An Investigation into the Problems of Teaching English at Primary Level
}

\author{
Mr.Jubraj Khamari ${ }^{1,}$ Dr. Nibedita Guru, Mr. Sanjeet Kumar Tiwari, \\ Ms.Nirupama Sahu, Dr. Parvinder Hanspal, Ms. Kshipra Hadke, \\ Ms. R. Sapana Naidu \\ ${ }^{1}$ School of Education, MATS University, Arang, Raipur,(C.G.), INDIA \\ ${ }^{2}$ School of Education RNIASE Cuttack, Utkal University, Odisha, INDIA \\ ${ }^{3}$ School of Education, MATS University, Arang, Raipur,(C.G.), INDIA \\ ${ }^{4}$ SSR College of Education ,SAYALI, Silvasssa ,Dadra and Nagar Haveli, INDIA \\ ${ }^{5}$ School of Education, MATS University, Arang, Raipur,(C.G.), INDIA \\ ${ }^{6}$ School of Education, MATS University, Arang, Raipur,(C.G.), INDIA \\ ${ }^{7}$ School of Engineering, MATS University, Arang, Raipur,(C.G.), INDIA
}

\begin{abstract}
Methodology of teaching English as well as teacher education program always has logic behind teacher education so as to teachers at primary level to higher secondary level in Indian school so far as nature of English language is concerned. Teaching English is a great task for English teacher to teach primary school students in multilingual society like India where English plays an important role however may be the different teacher training program like D.Ed., B.Ed., M. Ed. etc on the availability of trained teachers. Hence researchers in this research studies focus on the investigation on the problems of teaching English at primary level selecting 200 samples out of total population have proceed the research with required statistical methodology to identify the problem and suggest the remedial measure so as to findings and conclusion of this research work will be successfully analyzed and interpreted.
\end{abstract}

\section{INTRODUCTION}

"If language is not correct, than what is said is not what is meant, if what is said is not what is meant, then what ought to be done, remains undone"- Confucius

English is a foreign language. Fortunately or unfortunately, it continues to be one of the teaching subjects at the school and college level, and the teaching of this language has a dominating influence over the whole structure of our educational system. Every one new feels that a crisis has arisen in the education of our country. Evidences from a variety of sources shows in a very striking manner that a high percentage of our pupils in schools and colleges have very poor achievement in English. Even after eight years of learning English, they are not able to use the language with accuracy, propriety and effectiveness, as a result of which there is a vast amount of wastage and stagnation.

This has caused a great concern not only to the teachers and their pupils, but also to the parents, educators and administrators. in our teaching and learning practice. It is undoubtedly a major stumbling block and very little progress in education will be possible unless something is done to get over this obstacle. Hence researchers do a research on "an investigation into the problems of teaching English at primary level".

\section{Method And Design Of The Study}

\subsection{Statement of the Problem:-}

"An Investigation into the Problems of teaching English at Primary Level"

\subsection{Objective of the Study:-}

i. To determine the problems of teaching English in Primary Schools.

ii. To find out the causes of such problem.

iii. To recommend remedial measures for minimizing the evils of such problems.

Core has taken to collect information, statistics, views, remarks etc. from the schools, the district inspectors and the circle inspector. The techniques adopted for the investigation of the problems are accessibly of a survey nature and contribute the following steps:

a. Administration of suitable questioner to the teachers teaching English in primary schools

b. Visiting schools and studying records and reports concerned

c. Collection of data from other possible sources such as books and journal 


\subsection{Scope of the Study:-}

The researchers have confined the scope of the study to all the primary schools in Raipur districts of Chhattisgarh state only.

\subsection{Delimitation of the Study:-}

The study is delimited to 10 schools of the district of Raipur of Chhattisgarh state.

\subsection{Method of the Study:-}

The researchers have followed the Descriptive Survey Method to full fill the needs and complete this research work successfully.

\subsection{Sample of the Study:-}

The researcher has taken fifty primary teachers of Raipur town as the samples of the study.

\subsection{Tools and Techniques of the Study:-} study.

For this study the researchers have used questionnaire and simple statistical techniques for the

\subsection{Procedure of the Study:-}

To collect detailed information, statics views remark etc from the schools sub inspectors the district inspectors and the circle inspector

The techniques adopted for the investigation of the problem are of descriptive survey in nature and contribute the following steps.

i. Administration of suitable questionnaire to the teacher teaching English in primary schools.

ii. Interviewing with teachers, parents and guardians.

iii. Visiting schools and studying records and reports concerned.

iv. Collection of data from other possible sources such as book and journals.

These questionnaires and interviews are administrated to fifty primary school teachers of ten primary school of Raipur town. A large number of parents and guardians of the pupils have been interviewed.

III. ANALYSIS AND INTERPRETATION

TABLE NO- 3.1

\begin{tabular}{|l|l|l|}
\hline Academic Qualification & No. Of Teachers & Percentage \\
\hline Metric & 40 & $80 \%$ \\
\hline Intermediate & 05 & $10 \%$ \\
\hline Graduate & 03 & $6 \%$ \\
\hline Post Graduate Total: $50 \quad 02$ & $4 \%$ \\
\hline \multicolumn{2}{|l|}{ Total: $100 \%$} & \\
\hline
\end{tabular}

Table No.1 shows that most of the teachers are matriculates. They constitute 80 percent of the total number. The intermediate primary teachers stand second in the list. They are five in number, out of 50, constituting 10 percent. The Graduates are three in number constituting 6 percent. The post graduates are two in number and constituting 4 percent.

In the past most of the primary school teachers were mostly non-matriculation. It is a good sign now that most of the teachers are teaching English are matriculation. It is undoubtedly time that the situation has improved but not to the expected arid desirable extent but it is pity to say that the teachers performance are not up to the mark.

TABLE NO - 3.2

\begin{tabular}{|l|l|l|}
\hline Professional Qualification & No. Of Teachers & Percentage \\
\hline E.T. & 15 & $30 \%$ \\
\hline D.Ed. & $24+6$ & $48 \%+12 \%$ \\
\hline B.Ed. & 5 & $10 \%$ \\
\hline Total & $15+30+5=50$ & $88 \%+12=100 \%$ \\
\hline
\end{tabular}

None of the schools possesses an untrained teacher teaching English. The teachers are all E.T., 
D. Ed or B.Ed. We are glad to find that all the teachers are trained and most of them are D.Ed. They are definitely teaching better than the E.T. ones. But most of them lack both in content knowledge and method of teaching. They cannot maintain fluency while teaching English.

TABLE NO. 3.3

\begin{tabular}{|l|l|l|l|}
\hline Period of Service As a Teacher & Range of Service & No. of teacher & Percentage \\
\cline { 2 - 4 } & 1 to 5 years & 9 & $18 \%$ \\
\cline { 2 - 4 } & 6 to 10 years & 11 & $22 \%$ \\
\cline { 2 - 4 } & Above 10 years & 30 & $60 \%$ \\
\cline { 2 - 4 } & Total & 50 & $100 \%$ \\
\hline
\end{tabular}

The above table shows the total period of service of the teachers. It is found that 18 percent of the teachers fall under the range of six to ten years there are nine out of fifty, eleven teachers fall under the range of six to ten years constituting 22 percent. There are thirty out of fifty teachers fall under the range of above ten years constitution 60 percent. Thus most of the teachers are experienced but they are less qualified. The teachers falling in the range of one to five years are very young of tender age. They may not be dealing with the subject as well as the pupils effectively. There are 22 percent of the teachers having the experience of more than six years to ten years. I can be expected that they have been dealing with the subject more effectively.

Table No.3.4

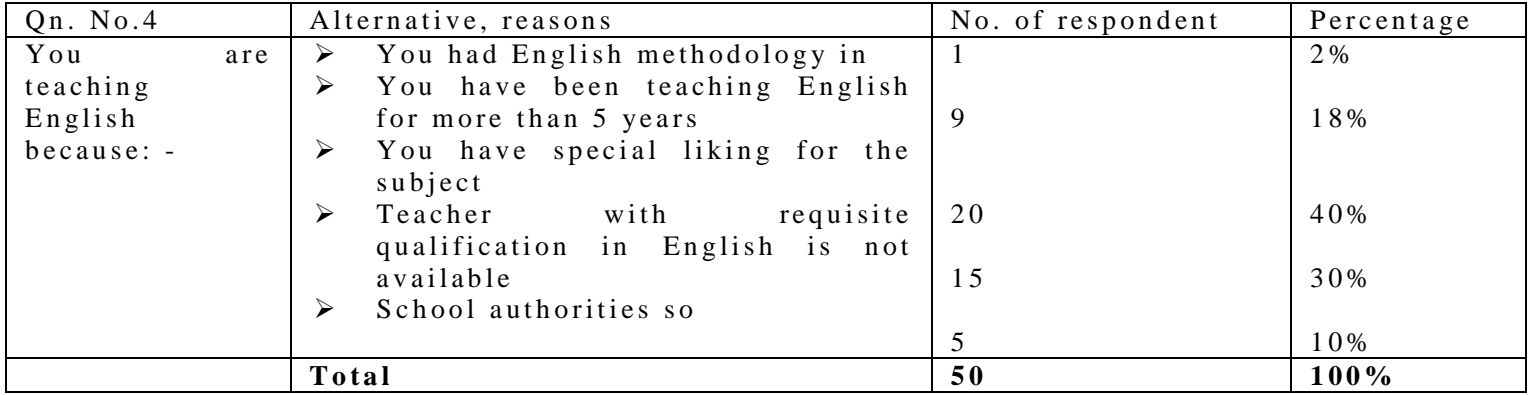

The teachers having completed either E.T. or D.Ed. must have read the methods of all the subjects equally as per provision. No special wastage is impaired upon any of the single methodology. Soothe teachers do not teach English necessarily that they had English methodology in their training period. Twenty out of fifty teachers, constituting 40 percent respond that they teach English because they have special liking for the subject. Nine teachers constituting 18 percent respond that they teach the subject because they teach it for more than five years. Fifteen teachers constituting 30 percent teach English because no teacher with requisite qualification is available. These teachers are primarily matriculates, having D.Ed. or E.T. as professional qualification. Five teachers out of fifty, thus constituting 10 percent teach English on the demand of authorities concerned. This aggravates the problem to a great extent. Only one teacher has the English method in B.Ed. it shows the about the about the problem.

\section{Orientation of the teachers:-}

Orientation is an essential requirement on the part of the teachers for widening his out-look, his horizon of knowledge and for training him in more dynamic methods of teaching. The refresher course, In-service training and seminars on English are also conducted to widen the outlook of the teachers and to provide fresh contact with the subjects and methods of teaching. These are really essential techniques for bringing about improvement in teaching. But to or utter disappointment on toe the teachers has ever attended a single course. When the scholar asked about the reason for doing so their reply was that not a single course of this type has ever been conducted. It is sorry to say that the government does not realize the importance of these programs.

Everybody now realizes that the standard of English is gradually going down in the primary schools. The author had put forth a list of reasons in his questionnaire to elicit the proper responses with which the teachers agree the most the following table throws sufficient light on this aspect. 
Table No. 3.5

\begin{tabular}{|l|l|l|l|}
\hline Sl. No. & Alternative reasons & No. of respondents & Percentage \\
\hline a. & The course is heavy & 49 & $98 \%$ \\
\hline b. & There is no provision of sufficient periods in the time table & 41 & $82 \%$ \\
\hline c. & $\begin{array}{l}\text { Most of the teachers teaching English are untrained in the concerned } \\
\text { method }\end{array}$ & 50 & $100 \%$ \\
\hline d. & The textbooks are not suitable & 40 & 50 \\
\hline e. & The number of English teachers in Schools is not sufficient & $50 \%$ \\
\hline f. & Most of the schools do not have sufficient teaching aids & 48 & $100 \%$ \\
\hline g. & The progress of the pupils is not frequently assessed & $96 \%$ \\
\hline h. & More emphasis is laid on the memory of the pupils & 45 & $90 \%$ \\
\hline i. & Writing of the pupils is to emphasized & 45 & $90 \%$ \\
\hline j. & The parent are illiterate & 47 & $94 \%$ \\
\hline k. & There are administrative difficulties in the school & 40 & $80 \%$ \\
\hline l. & The Schools are not timely supervised & 29 & $58 \%$ \\
\hline m. & The authorities do not provide proper guidance to the teacher. & 81 \\
\hline n. & The teachers are not interested to teach English. & 41 & $82 \%$ \\
\hline o. & The students come of, mainly poor families. & 41 & $82 \%$ \\
\hline p. & The pupils do not like to learn English & 27 & $82 \%$ \\
\hline q. & The parents do not like their children to learn English & \\
\hline
\end{tabular}

Table No.5 shows that forty nine out of fifty teachers, constituting 98 percent respond that the course is heavy. The course is not suitable for the immature brains of the students. They cannot cope up with the course. Forty one out of fifty teachers constituting 82 percent say that there is no provision of sufficient periods in the time table. On personal contact they said to the author that English is a foreign language. The students find it difficult to learn it. So it would be better than there would be provision of more of periods for teaching English. This would provide more time for practice. The respondents unanimously agree that most of the teachers teaching English are untrained in the method of teaching English though they possess a certificate of E.T., D. Ed or B.Ed. There is no provision of conducting orientation courses, in-service training or seminars which might help them to know about the modem method of teaching English.

Forty out of fifty teachers constituting 80 percent are of opinion that the text books are not suitable. The text books should be modified, revised in close collaboration with the teachers having long-standing experience in this field.

The respondents are of opinion that the number of English teachers in schools is not sufficient. They say that tile number of English teachers should be sufficient as the teaching of English needs proper handling. It so happens that in some schools there is insufficient teachers. The teachers teaching English is required to teach other subjects. He remains engaged in some other school activities So he never finds time to think seriously about effective teach ${ }^{\mathrm{i}} \mathrm{ng}$ But it is needless to say that the teacher should get sufficient time for preparing English lesson. It is also very difficult on the part of the part of the teacher of English to adjust to double class system the government remains silent in this regard.

Forty eight out of fifty respondents, constituting 96 percent are of the opinion that most of the schools do not have sufficient teaching aids. The important of teaching aids in English teaching can never be over emphasized. For drilling good new structures needs a good number of audio-visual aids. But almost all the Schools do not have sufficient number of aids.

Forty out of the fifty teachers constituting 90 percent opine that the progress of the pupils is not frequently assessed. They solely depend upon the hold-yearly and Annual Examinations. Some make provision of quarterly examination. But it is not sufficient. The more the number of assessments, it is the better. The teacher should, from time to time, know the progress of the pupils.

Forty five out of fifty teachers constituting 90 percent agree that more emphasis is laid on the memory of the pupils. The teachers do not give stress upon the understanding on the part of the students. Rather they give stress upon the mere cramming. It is one of the faults in the teaching English in our State.

The table shows that forty seven respondents constituting 94 percent are of the opinion that emphasis on writing of the pupils are not laid. So the handwriting of the pupils becomes miserably bad. This factor also results in a large number of spelling errors.

Forty respondents out of 50, constituting 80 percent are of the opinion that the parents are illiterate. It affects the learning of English. But it does not appear to be a potent factor. It the teacher takes sincere steps, he may make up this deficiency caused due to illiteracy of parents.

Twenty nine teachers constituting 58 percent opine that the administrative difficulties in the schools are the stumbling blocks on the way of teaching English. There remains continuous conflict among the teachers and the teachers on one hard and the inspecting officers on the other.

Forty one respondents, constituting 82 percent, are of opinion that the schools are not timely 
supervised. Most of the primary schools are situated not visited by the Inspections. Due to the extreme negligence and carelessness on the part of the inspecting officers some schools remain unsupervised for years together.

Forty one teachers, constituting 82 percent, are of opinion that the authorities do not provide proper guidance to the teachers teaching English.

Some forty one teachers constituting 82 percent are of the opinion that the teachers are not interested in teaching of English. Some lack sufficient qualification, some lack sufficient training and others are indifferent.

Twenty seven teachers constituting 54 percent are of opinion that the students come from poor family. They cannot purchase reading materials even. Some twenty seven teachers constituting 54 percent opine that the pupils do not like to learn English. I think this is mainly due to the ineffective method of teaching English. The teachers are unable to create interest in the pupils. The pupils are not properly motivated.

Fifty teachers opine that the parents want their children to learn English. to know the world, other 50 percent teachers opine that the parents do not want their children to learn English because they cannot answer the question asked by the children. A gap is created between the parents and the children due to English. It may be but for this there is the degradation of standard in English.

\section{Text Book:-}

The text- book is the most important tool for teaching the language skill and very important source of information. But the text books also contain several major defects. The following table gives a very good picture in this direction.

Table No. 3.6

\begin{tabular}{|c|c|c|c|c|c|}
\hline Q. No & Alternative responses & Yes responses & Percentage & No responses & Percentage \\
\hline i. & $\begin{array}{l}\text { Text Books are prescribed and } \\
\text { prepared by the board }\end{array}$ & 50 & $100 \%$ & 0 & $0 \%$ \\
\hline ii. & Topics are not properly arranged & 46 & $92 \%$ & 4 & $8 \%$ \\
\hline iii. & $\begin{array}{l}\text { Structures have not been properly } \\
\text { graded }\end{array}$ & 47 & $94 \%$ & 3 & $6 \%$ \\
\hline iv & $\begin{array}{l}\text { Language written in the book is } \\
\text { difficult }\end{array}$ & 50 & $100 \%$ & 0 & $0 \%$ \\
\hline $\mathrm{V}$ & $\begin{array}{l}\text { Topics should have been illustrated } \\
\text { with more pictures }\end{array}$ & 50 & $100 \%$ & 0 & $0 \%$ \\
\hline vi & $\begin{array}{l}\text { Pictures given in the text book are } \\
\text { not very attractive }\end{array}$ & 49 & $98 \%$ & 1 & $2 \%$ \\
\hline vii & All pictures are not very appropriate & 49 & $98 \%$ & 1 & $2 \%$ \\
\hline viii & $\begin{array}{l}\text { The topics selected, do not create } \\
\text { interest in the pupils }\end{array}$ & 45 & $90 \%$ & 5 & $10 \%$ \\
\hline ix & The books exercises are not adequate & 46 & $92 \%$ & 4 & $8 \%$ \\
\hline $\mathrm{x}$ & $\begin{array}{l}\text { The text book are not designed to } \\
\text { meet the demands of the structural } \\
\text { syllabus }\end{array}$ & 42 & $84 \%$ & 8 & $16 \%$ \\
\hline
\end{tabular}

The above table shows that the text-books are defective. The teachers unanimously respond that Textbooks are prescribed and prepared by the Board. Language used in the books is difficult and Topics should have been illustrated with more pictures. 98 percent respondents are of the opinion that pictures given in the text-books are neither attractive nor very appropriate. They do not create interest in the pupils. The above table also shows that topics are not properly arranged and structures have not been properly graded. The persons in the charge of preparation of books do not prepare text-books suiting to the mental level of the pupils, when the scholar went through the text-books he found that the pictures are not very much in appropriate. Topics have been properly arranged. But the difficulty is that the teachers lack sufficient knowledge to understand them. Some other respondent opine e that the topics selected, do not create interest in the pupils, the book exercises are not adequate and the textbooks are riot designed to meet the demands of the structural syllabus. But the author found that there is title truth in all these complaints. But the lack of sufficient knowledge, proper training regarding structural syllabus and modern method of teaching English leads them to such beliefs.

\section{Preparation of the Teachers:-}

A teacher can do justice to his subject only when he comes through prepared to the class. The intensity of preparation depends largely upon the length of experience of the teacher. An old and experienced teacher who has taught English for several years needs very little preparation. The table given below throws sufficient light in this regard.

The reasons, unanimously agreed upon, are correction of a large number of written works and teaching 
load is too heavy. The teachers teach some other subjects besides English. Some complain that they have to remain busy in other school affairs. But their percentage is very low, $6 \%$ only.

TABLE NO. 3.7

\begin{tabular}{|l|l|l|l|}
\hline Q. No. & Alternative Reasons & No. of respondents & Percentage \\
\hline $\begin{array}{l}\text { Reasons for not } \\
\text { preparing lesson } \\
\text { plans }\end{array}$ & a. There is a lot of written book to be corrected & 50 & $100 \%$ \\
\cline { 2 - 5 } & b. You have to teach some other subject too. & 50 & 3 \\
\cline { 2 - 5 }
\end{tabular}

Method:-

Method of teaching influences the effectiveness of teaching and ultimately it affects the achievement of pupils. It is very crucial in primary schools, because the teacher is to deal with small pupils who are completely new to the subject. The following table makes it quite clear.

TABLE NO.3.8

\begin{tabular}{|l|l|l|l|}
\hline S1. No. & Name of the Method & No. of teaching following & Percentage \\
\hline i. & Translation Method & 25 & $50 \%$ \\
\hline ii. & Direct Method & 13 & $26 \%$ \\
\hline iii. & Translation cum Direct Method & 37 & $74 \%$ \\
\hline
\end{tabular}

The above table shows that 50 percent of the respondents purely and solely take recourse to Translation Method. They do not have sufficient knowledge of the modern techniques of the teachers respond that they follow the Direct Method of Teaching English in lower classes. They are certainly trained once with at least a little bit of liking for the subject. Most of the teachers, constituting 74 percent, follow the translation-cumDirect Method. Most of the teachers teach English in combination of two to three methods. None of them strictly follow the Direct Method of Teaching English through Structural Approach. They agree on the point that lack of training and non- Availability of teaching materials discourages them to follow new methods.

The teacher of English is required to be familiar with the structures which are required to be deal with. In order to know the familiarity of the teachers with the structures the scholar had asked the question No. 36 teachers out of constituting 72 percent have responded their familiarity with the structures. The rest 28 percent have responded their unfamiliarity.

TABLE NO. 3.9

\begin{tabular}{|l|l|l|l|l|}
\hline Question & Yes & Percentage & No & Percentage \\
\hline Are you thoroughly familiar with the structures to be taught & 36 & $72 \%$ & 14 & $28 \%$ \\
\hline
\end{tabular}

TABLE NO. 3.10

\begin{tabular}{|l|l|l|l|l|l|}
\hline Sl. No. & Question & Yes & Percentage & No & Percentage \\
\hline a. & $\begin{array}{l}\text { Do you drill the old structures before you begin the } \\
\text { new lesson? }\end{array}$ & $76 \%$ & 12 & $24 \%$ \\
\hline b. & Do you drill the new structures before reading? & 38 & $76 \%$ & 12 & $24 \%$ \\
\hline C & $\begin{array}{l}\text { Do you give stress upon the "students Loud } \\
\text { Reading"? }\end{array}$ & 49 & 1 & $2 \%$ \\
\hline
\end{tabular}

The above table throws sufficient light on the teachers dealing with the structures. Thirty eight teachers constituting 76 percent respond that they deal with the old and new structures respectively before reading the lesson. 24 percent teachers neither knows regarding the structures nor do they deal with them. They do not have sufficient training. 98 percent of the teachers stress upon the "Students Loud Reading". The teachers do not possess sufficient knowledge of phonetics. They do not pronounce properly. So the student's pronunciation is not so good.

It has been found by the scholar that none of the teacher follows the "Structural Approach" in teaching English. To know about the reasons the scholar has set a list of questions in his questionnaire. The following table gives some information.

TABLE NO. 3.11

\begin{tabular}{|l|l|l|l|}
\hline Sl. No. & Alternative Reason & No. of respondent & Percentage \\
\hline a. & Teachers lack training in it. & 50 & $100 \%$ \\
\hline b. & There is less time at teachers disposal. & 38 & $76 \%$ \\
\hline c. & $\begin{array}{l}\text { Methodical teaching hampers covering syllabus in the prescribed } \\
\text { time }\end{array}$ & 39 & $78 \%$ \\
\hline d. & Other methods are easier to follow & 36 & $72 \%$ \\
\hline e. & No suitable aids are available & 50 & $100 \%$ \\
\hline
\end{tabular}




\begin{tabular}{|l|l|l|l|}
\hline F. & The students are not benefited by the Structural Approach & 36 & $72 \%$ \\
\hline g. & Lack of English atmosphere in the class & 50 & $100 \%$ \\
\hline h. & It is not practicable & 31 & $62 \%$ \\
\hline
\end{tabular}

The above table shows that the respondents are unanimous in attributing the cause of not following the Structural Approach is:

i. Teachers lack training in it.

ii. No suitable aids are available.

iii. Lack of English atmosphere in the class.

72 percent to 78 percent respondents are of the opinion that the Structural Approach is not followed due to:

i. There is less time at teacher's disposal.

ii. Methodical teaching hampers covering the syllabus in time.

iii. Other methods are easier.

iv. The students are not benefited by it.

62 percent teachers are of the opinion that it is not practicable.

But the scholar is of the opinion that the structural approach is not followed in the schools because the teachers lack training in it and no suitable aids are available. It is practicable and English atmosphere in the class can be easily created if the teacher tries sincerely.

\section{Pupil Participation:-}

The modern system of education lays the great stress upon the child. He should be active throughout teaching. We are now aiming at child-centric education. But it is a matter of great regret that the students in the English classes in primary schools remain passive. Their participation in teaching is next to nothing. In order to find out the causes the scholar had set a number of probable and alternative reasons in her questionnaire. The findings are well evident from the following table.

TABLE NO. 3.12

\begin{tabular}{|c|c|c|c|c|c|}
\hline Sl. No. & Alternative reasons & Yes & Percentage & No & Percentage \\
\hline a) & $\begin{array}{l}\text { The structural Approach does not appear } \\
\text { interesting }\end{array}$ & 42 & $84 \%$ & 8 & $16 \%$ \\
\hline b) & They don't come prepared to the class & 48 & $96 \%$ & 2 & $4 \%$ \\
\hline c) & They don't clarify their doubts and difficulties & 49 & $98 \%$ & 1 & $2 \%$ \\
\hline d) & They do not ask question in the class & 49 & $98 \%$ & 1 & $2 \%$ \\
\hline e) & They are afraid of making mistakes & 50 & $100 \%$ & 0 & $0 \%$ \\
\hline f) & $\begin{array}{l}\text { It is not always possible to motivate them } \\
\text { properly }\end{array}$ & 48 & $96 \%$ & 2 & $4 \%$ \\
\hline g) & Suitable aids are not used & 49 & $98 \%$ & 1 & $2 \%$ \\
\hline h) & Most of the talking is done by the teacher & 48 & $96 \%$ & 2 & $4 \%$ \\
\hline
\end{tabular}

It could be soon from the above table that all the respondents are in agreement with the researcher that students do not practicable in the teaching of English in their class room because they are afraid of making mistakes. They lack practice. The teachers follow the Translation Method. There is very little scope for the pupil to express in English.

98 percent respondents are of the opinion that the pupils do not take part actively in their class room reading because:

1. They don't clarify their doubt and difficulties.

2. They don't ask question the class.

3. Suitable aids are not used in the teaching of English.

96 percent teachers admit that the students never come prepared to the class and it is not always possible to motivate them. The teachers lack might have otherwise profitably employed. The teacher talks more and thus leaving no scope for students. The teacher has to complete his lessons in prescribed time.

\section{Availability of Teaching Aids:}

Teaching aids have a very important role in the teaching and learning process. They serve a variety of purposes and the effectiveness of teaching depends to a great extent upon the careful handling of different types of teaching aids.

In the teaching of English in the Direct Method through Structural Approach in the lower classes and when the use of the learners Mother Tongue is reduced to minimum the teaching aids have a very important role to play for effective teaching of the subject. It was not possible to include an exhaustive list of aids in the questionnaire. The important aids however, are included. The teachers were asked to mark a tick $(\sqrt{ })$ against the aids which their schools possess. Availability of these aids in the schools has been tabulated below:- 
TABLE NO.3.13

\begin{tabular}{|c|c|c|c|c|c|}
\hline Sl. No. & Question & Yes & Percentage & No & Percentage \\
\hline a. & $\begin{array}{l}\text { Do you make use of any audio visual aids while } \\
\text { teaching English }\end{array}$ & 7 & $14 \%$ & 43 & $86 \%$ \\
\hline b. & $\begin{array}{l}\text { Do you improvise any aids for the teaching of } \\
\text { English? }\end{array}$ & 10 & $20 \%$ & 40 & $80 \%$ \\
\hline
\end{tabular}

TABLE NO.3.14

\begin{tabular}{|l|l|l|l|}
\hline Sl. No. & Name of the aids & No. of Schools possessing & Percentage \\
\hline a. & Pictures & 50 & $100 \%$ \\
\hline b. & Models & 49 & $98 \%$ \\
\hline c. & Radios & 07 & $14 \%$ \\
\hline
\end{tabular}

Tables No.13 shows that 14 percent of the total number of teachers use audio-visual aids while teaching English, where as 86 percent do not 20 percent teachers use some aids, though not audiovisual where as 80 percent do not use any sort of aids. This shows about the condition of primary schools. But most of the teachers declare that the use of aids is essential.

Table No.14 shows indicates that some schools possess picture, models and radios. All the schools possess pictures. They are either drawn by the teachers or pupils. Most of the schools possess models also.

\section{Library:-}

The importance of Library facilities in schools can badly be over emphasized. Text-books are never the only source of information. For enhancing the outlook of the pupils, creating interest in the subject and acquiring knowledge, the library is highly necessary. A flood and well equipped library when properly utilized serves all the purposes. But it is a matter of great regret that some schools in our State do not have library. Even if there is library they are poorly equipped. So that neither the students nor the teachers do not get any help out of it. The following table throws sufficient knowledge in this regard.

TABLE NO.3.15

\begin{tabular}{|l|l|l|l|l|l|}
\hline Sl. No. & \multicolumn{1}{|c|}{ Alternative Question } & Yes & Percentage & No & Percentage \\
\hline a. & Is there library in your school where you teach? & 45 & $90 \%$ & 5 & $10 \%$ \\
\hline b. & Do you get any help from the library? & 10 & $20 \%$ & 40 & $80 \%$ \\
\hline
\end{tabular}

\section{Home Task:-}

Its importance in the field of education is unquestionable, because of the fact that it provides ample provision for the application of knowledge and for his fixation in the students.

It also whereas a process of evaluation. The teacher should judiciously plan the nature and amount of home task realizing the importance of home task the researcher has set a list of different types of periodic home tasks which will be clear from the following, table.

TABLE NO.3.16

\begin{tabular}{|c|l|l|}
\hline Type of periodic home task & No. of respondents & Percentage \\
\hline Daily & 33 & $66 \%$ \\
\hline Occasionally & 17 & $34 \%$ \\
\hline
\end{tabular}

The respondents are of opinion that home tasks should be given to the pupils. All of them also agree that they give home tasks to the pupils. But 66 percent of them give daily time tasks whereas 34 percent give occasionally.

\section{Correction work:-}

As correction work forms as essential part of the evaluation Process some questions on it were also included in the questionnaire. The respondents are unanimous in the following types of correction -

(i) Correction by himself in the class

(ii) Correction by himself at home discussion.

They never adopt the profitable method of correction by the pupils in the class itself through

The researcher don't feel the necessarily of giving a table of response because all the respondents follow the two procedures of corrections. 


\section{Test and evaluation:-}

Test and evaluation are the integral part of the teaching process. Evaluation actually plays a prominent role in influencing the instructional process and the effectiveness of the teaching. Most frequent examination will result in stimulating the pupils interest in study and ultimately in better under testing and better attainment.

The other important value of the examination is that it reveals the weak points in learning process. Their results also serve as an incentive for learning. Therefore examination is one of the devices which is responsible for satisfactory Performances. Because of the importance of tests and evaluation several questions were included in the prescribed section of the questionnaire.

\section{Findings:-}

It is found that all the schools conduct only quarterly examination besides the Annual and the Halfyearly. They don't understand the value of periodic examination frequently occurred.

\section{Handwriting:-}

Handwriting is also an important aspect of the child education. A clear handwriting is always praised. It leads to organized writing. A bad handwriting is prone to spelling-error. Realizing the importance of handwriting the scholar had set a list of questions in her questionnaire to know why the handwritings of the pupils are miserably bad.

TABLE NO. 3.17

\begin{tabular}{|c|l|l|l|}
\hline Sl. No. & Alternative reasons & $\begin{array}{l}\text { No. of Schools } \\
\text { possessing }\end{array}$ & Percentage \\
\hline i. & They do not write handwriting regularly. & 50 & $100 \%$ \\
\hline ii. & Dictation work is not done in the class & 44 & $88 \%$ \\
\hline iii. & $\begin{array}{l}\text { Even if the dictation work is done bad handwriting is not } \\
\text { marked }\end{array}$ & 45 & $90 \%$ \\
\hline iv. & Teachers are indifferent towards the handwriting of the pupils & 46 & $92 \%$ \\
\hline v. & Students do not get proper guidance the pupils & 49 & $98 \%$ \\
\hline vi. & There is no provision of rewards for good handwriting & 50 & $100 \%$ \\
\hline
\end{tabular}

Table No.17 elucidates that 100 percent respondents agree with the scholar that handwriting of the pupils is had due to irregular writing and absence of rewards for good handwriting. Besides this the following Reasons also go a long way in causing had handwriting on the part of pupils.

i. Teachers are careless in their writing. They do not realize that pupils are best imitators. If they are neat in their writing it will influence them.

ii. Teachers are very often indifferent towards their pupils writing. They do not provide necessary guidance. They simply sign on the note book without giving any instruction.

iii. Some 88 percent to 90 percent teachers are of the opinion that dictation work is not done in the class and even it is done, bad handwriting is ignored.

\section{Improvement for slow learners:-}

There are some backward children who need special care and attention. In order to know the steps taken by the teachers in this direction, the scholar has included a list of questions in her questionnaire The following table gives some of the teacher's responses.

TABLE NO. 3.18

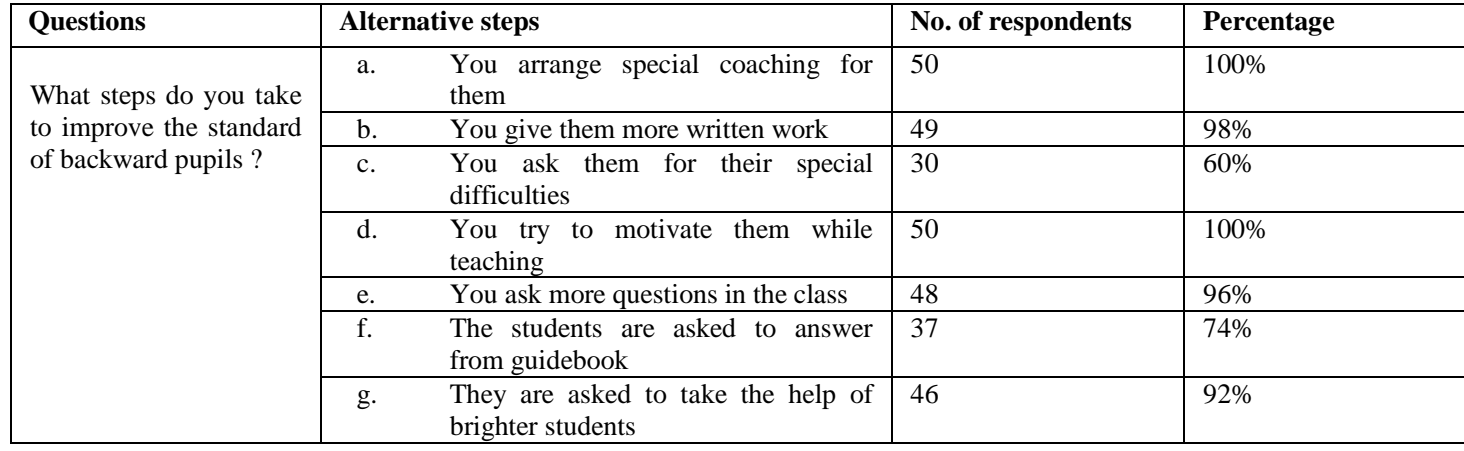




\begin{tabular}{|c|cl|l|l|}
\hline & h. & $\begin{array}{l}\text { Their parents are informed with } \\
\text { reports }\end{array}$ & 32 & $64 \%$ \\
\cline { 2 - 5 } & i. & $\begin{array}{l}\text { Their parents are informed with } \\
\text { reports }\end{array}$ & 16 & $32 \%$ \\
\cline { 2 - 5 } & j. & $\begin{array}{l}\text { Students are assigned with question } \\
\text { form topic already taught. }\end{array}$ & 24 & $48 \%$ \\
\hline
\end{tabular}

i. They arrange special coaching which is otherwise known as remedial work

ii. Students are very poor in handwriting. So they are asked to do more written work.

iii. The students are not interest to learn English. They remain passive in the class. So the teachers try to motivate them properly.

Most of the teachers give private tuitions. They also instruct the parents to arrange for tuitions. But in their responses only 32 percent agree with it.

\section{Discussion And Recommendation}

\subsection{Discussion:-}

The scholar in course of collecting the respondent - questionnaire came in close contact with many a teacher, she has also met with the circle inspector and District Inspector of Schools concerned. Their suggestions for improving the standard of English may be summarized thus:

i. Textbooks are to be written in accordance with the standard and interest to the pupils. This should be drawn in consultation with the teachers.

ii. Training in phonetics should be given to the teachers.

iii. The students should be supplied with English books suitable to their standard.

iv. The syllabus should be properly graded.

v. Translation should be introduced from lower classes.

vi. The syllabus should be changed with a view to increasing the reading habit of the pupils.

vii. Syllabus should be more carefully planned so that teacher will be in position to know what he is going to do and to know how he is acing to do it.

viii. Libraries should be improved.

ix. More trained teachers should be appointed to teach English.

$\mathrm{x}$. Some refresher courses should be conducted so that teachers can be benefited.

xi. The classes should not be over crowded and teacher pupil ratio must be adequately maintained.

xii. More time should be allotted for drilling.

xiii. Emphasis on mere cramming and memory work should be withdrawn.

xiv. Due stress should be given on the power of expression.

xv. Prizes should be awarded for good handwriting.

xvi. Administrative difficulties should be removed.

\subsection{Recomendation:-}

Teachers:-

So far as the qualification of the teachers of English is concerned, he should be at least a degree holder with Teachers Training Diploma in English or B.Ed. with English Method.

Orientation programs are essential for the teachers of English for widening their outlook and for acquainting them with the latest trend of teaching the subject. The teachers should themselves feel inclined to participate in such programs and the authorities should also pay a little more attention to this fact.

Without adequate teachers preparation the teaching-learning process can never be as effective as it should be. Preparation enables the teacher to develop new insight to the contents and process of learning as well.

The teacher should keep in his mind that he is the friend, philosopher and guide of the students. The pupils are very delicate and are at very tender age. So they should be looked upon sympathetically. Detecting the disabilities of the pupils and teaching them correct language habits are the important duties of the language teacher. Instead of depending on stereo type convictism a good teacher should always be on the look-out for anything fresh and interesting which promises to improve his techniques and the subject more interesting for his class. 
Text Books:-

The text-books play a very important role in the teaching-learning process. The gradation of the structures is very important. The exercising the text-books should be properly placed. The lessons should contain attractive, accurate and appropriate pictures. It is very often found that the language used in the textbook is beyond the reach of the students. It should be avoided. The languages should be so simple that it should be within the reach of the students.

\section{Teaching Materials:-}

Teaching materials play an important role in the scheme of teaching English in primary schools. The role of pictures, models, pictorial magazine, projector, tape-record, radio, film strips, computer, television can't be minimized.

We have to form clear concepts in the minds of the students. So pictures and other audio-visual aids are quite essential. We know that Orissa is primarily a very poor provide. But the teacher should know that without any expense he can prepare some audio-visual aids himself or with the help of students. They can be profitably. The Government should come forward to sanction some monetary grants whereby some audio-visual aids can be bought. It would be better if the government gives these in forms of materials rather than money.

Keen and sincere steps should be taken in this direction, because this is the very important stage in the child's educational life. Once clear and accurate concepts are formed in this formative stage it will last throughout his life.

\section{Preparation of Lesson Note :-}

Preparation is pre-requisite to good teaching. But none of the teachers prepares it, so strict measures should be adopted so that each teacher should prepare his lesson note regularly.

\section{Method:-}

Many of the teachers still follow the traditional method of teaching-English like the Translation Method. Some teachers are even unaware of direct method through structural approach. So proper orientation programs should be made which will give them an avenue to know the modern and efficient techniques of teaching English in primary schools.

\section{Home task:-}

Proper care must be taken and instruction must be given so that the teachers give home-task regularly.

\section{Correction Work:-}

The teachers correct the home task either in class or home but their procedure of correction is not appropriate. The teacher should take steps so that the mistakes are corrected by the students first and then by him in case of general failure. The teacher should follow the discussion method.

\section{Test and Evaluation:-}

The two examinations half-yearly and annual are not sufficient. There should be a continuous system of evaluation at short intervals either weekly or fortnightly. -This would enable the teacher to assess his pupil's progress at short and regular intervals. The progress report should also be communicated to the parents of the pupils care should be taken by the head of the institution to record thorn properly well.

\section{Handwriting:-}

The hand-writing of the pupils in primary schools is generally, miserably bad. It can be rectified if the students write hand-writing regularly, dictation work is done in the class, students get proper guidance on hand writing and careless handwriting of the teachers is avoided and proper provision of rewards for good handwriting should be there in the schools.

\section{Library:-}

It is surveyed that there are libraries but there do not contain woeful books in the libraries. There should be books on teaching English, psychology, picture books, pictorial magazine suiting to the needs and interest of the pupils and teachers.

\section{Remedial Work:-}

The author is glad to find that in each arid every school there is provision of remedial work. But it is being done only twice a week. This is quite insufficient. Even if there is provision of remedial work the teachers 
are not doing it sincerely. Individual attention is not being given. The teachers should be sincere enough in the remedial work period.

\section{Parents:-}

Most of the parents are illiterate. They don't send their children regularly to schools. 1he teachers should not look down upon the parents for their illiteracy. They should be respected and the progress of their children should be communicated to them regularly. There should be provision of parents Teachers Meeting in the school.

\section{Administration and Supervision:-}

There should be provision of democratic supervision in the school system. The inspecting authorities cause perennial headache to the teachers demanding illogical gains. They do not supervise the schools regularly. Even if they supervise they cling close to the bygone pattern of supervision: finding out faults only. They do not give proper suggestions at guidance to the teachers. It would be worth-while if subject experts are appointed for this work should be worthwhile if subject experts are appointed for this work so that the teachers would get proper guidance from them.

\section{A Vital Issue:-}

The last but not the least suggestion is that a committee of experts should be appointed to make a survey of the present position of teaching English in the primary schools and recommend to the government whether English should be introduced at a later stage taking into active consideration the conditions prevailing in our schools. There is need for a more detailed and comprehensive study.

\subsection{Major Findings:-}

1. Most of the primary teachers are matriculates.

2. All the teachers are trained and most of them have done C.T. or D.I.E.T. But they lack in content knowledge and method of teaching.

3. Most of the teachers have been working for above ten years. Thus they are experienced teachers.

4. The teachers who are teaching English have a special liking for the subject.

5. Most of the teachers teaching English are untrained in the concerned method.

6. The progress of the pupils is not frequently assessed in the schools.

7. Writing of the pupils is not emphasized.

8. Text-books are prescribed and prepared by the board.

9. The topics of the text books are not properly arranged

10. The text books are not designed to meet the demands of the structural syllabus.

11. The number of the English teachers in schools is not sufficient.

12. The English teachers have to teach same other subjects also in the school.

13. Most of the teachers are following translation cum-direct Method.

14. No suitable aids are available in the schools.

15. There is no provision of rewards for good handwriting of the students.

16. Lack of English atmosphere in the classes' room while teaching English.

\section{Primary Sources:-}

\section{References:-}

\section{Journal Article:-}

[1]. Balsubramaniam N. (1991) Classroom Climate to Pupil's Achievement In English at H.S.C. The Journal of English Language Teaching

[2]. Vol. xxvi, No.1

[3]. Joshi B.(1997, September) The impact of visual aids in teaching English in of Secondary School Students The progress Education, Vol.

[4]. IXX II No.4

[5]. Khan I.A.(1995) Difficulties in the learning of English as a second language. The Educational review VOL.I

[6]. Krishna Murti, R.(1995, March) English necessary for new knowledge, The Progress of Educational VOL.IX No.8

\section{Books:-}

[7]. Buch M.B. (1978-83) second Survey by of research In Education, Baroda: Society for Education Research and

[8]. Development,

[9]. Buch M.B (1978-83) Third Survey of Research in Education, New Delhi, NCERT.

[10]. Buch M.B. (1988-92) Fifty Survey of Research in Education, New Delhi, NCERT.

[11]. Menon, T.K.N. and Patel M.S., The Teaching of English As A Foreign Language, Acharya Book Depot, Baroda, Second Revised. 
[12]. Gained D.N. and Sharma, R.P. (1963) Talks to Teacher of English in India, Ram Prasad and sons Agra UNESCO Publication, The Teacher

[13]. of Modern Language UNESCO.

[14]. Kochhar. S.K. Secondary School Administration, Sterling Publisher, New Delhi-16

Reports:-

[15]. Reports of Secondary Education Commission (1952-53) Ministry of Education and Social Welfare Gov. of India

[16]. Report of National Policy on Education ( 1968 ), Ministry of Education and Social Welfare, Government of India.

[17]. Report of National Policy on Education (1986), Ministry of Human Resource Development, Dept. of Education, New Delhi.

Thesis:-

[18]. Behra Sushant Kumar (2001) An investigation into the causes of failure in English unpublished M.Ed. dissertation Dr.P.M.I.A.S.E.,

[19]. Sambalpur University

[20]. Mahapatra Saroj Kumar (2001) Identification of learning difficulties of Secondary School students in English grammar unpublished M.Ed. dissertation Dr. P.M.I.A.S.E., Sambalpur

\section{Abstracts:-}

i. Abstract of M. Ed, M Phil Dissertation (1985-2007) Of Dr. P.M.I.A.S.E., Sambalpur, Odisha

\section{Secondary Sources:-}

Books:-

[21]. Best J. W. (1989) Research in Education (6 $6^{\text {th }}$ Edition) New Delhi, Prentice hall of India pvt.ltd.

[22]. Das, B.N. (1989) Teaching English (3rd edition): Cuttack: books and books

[23]. Kohil, A.L. (1996) Techniques of teaching English $\left(12^{\text {th }}\right.$ edition), New Delhi,

[24]. Dhanpad Rai and Sons. Kaul, Lokesh (1988) Methodology of educational Researcher (2 $2^{\text {nd }}$ edition) Delhi, Vikas publishing house. 